minium containing phosphate binders in children with azotemia not undergoing hemodialysis. $N$ Engl f Med 1984;310:1079-84

9 Clarkson EM, McDonald SJ, De Wardener HE. The effect of a high intake of calcium carbonate in normal subjects and patients with chronic renal failure.
Clin Sci 1966;30:425-38.

10 Moriniere PH, Roussel A, Tahiri Y, et al. Substitution of aluminium hydroxide by high doses of calcium carbonate in patients on chronic haemodialysis (1) hyperalumininaemia and equal control

roidism. Proc Eur Dial Transplant Assoc $1982 ; 19: 784-7$.
11 Brown HE. The evaluation of a new diet for children on haemodialysis pro-

12 Walton RJ, Bijvoet OLM. Nomogram for the derivation of renal threshold phosphate concentration. Lancet $1975 ; \mathrm{ii}: 309-19$.

13 Bijvoet OLM. Indices for the measurement of the renal handling of phosphate. In: Massry SG, Fleisch $\mathrm{H}$, eds. Renal handling of phosphate. New York: Plenum Medical Book Co, 1980:1-37.

14 Woo J, Singer FR. Radioimmunoassay for human parathyroid hormone. Clin Chim Acta 1974;54:161-8.

15 Tovey KC, Oldham KG, Whelan JAM. A simple direct assay for cyclic AMP in lasma and other biological samples using an improved competitive protein binding techniqe. Clin Chim Acta 1974;56:221-34.

16 Lawrence R. Assay of serum inorganic phosphate without deproteinisation

17 Chantler C, Barratt TM. Estimation of glomerular filtration rate from plasma clearance of 51-chromium edetic acid. Arch Dis Child 1972;47:613-7.

18 Counahan R, Chantler C, Ghazali S, et al. Estimation of glomerular filtration rate from plasma creatinine concentration in children. Arch Dis Child 1976;51

19 Portale AA, Booth BE, Halloran BP, et al. Effect of dietary phosphorus on circulating concentrations of 1,25 dihydroxy vitamin $D$ and immunoreactive parathyroid horm $1984 ; 73: 1580-9$.
20 Bricker NS. On the pathogenesis of the uremic state: an exposition of the "tradeoff hypothesis." N Engl f Med 1972;286:1093-9.

21 Rutherford WE, Bordier P, Marie P, et al. Phosphate control and 25 hydroxycholecalciferol administration in preventing experimental renal osteodystrophy in the dog. $\mathcal{F}$ Clin Invest 1977;60:332-41.

22 Ibels LS, Alfrey AC, Haut $\mathrm{L}$, et al. Preservation of function in experimental renal disease by dietary restriction of phosphate. $N$ Engl $\mathcal{F}$ Med 1978;298:122-6. Llach F, Massry SG, Koffler A, et al. Secondary hyperparathyroidism in early renal failure: role of phosphate retention (Abstract). Clin Res 1977;25:507A. ionixed calcium immunoreactive parathyroid hormone, and aluminium in chronic renal failure. $\mathrm{Br}$ Med $\mathcal{f} 1982 ; 284: 776-8$.

25 Brown EM, Wilson RE, Eastman RC, Pallotta J, Marynick S. Abnormal regulation of parathyroid hormone release by calcium in secondary hyperparathyroidism due to chronic renal failure. $\mathcal{F}$ Clin Endocrinol Metab 1982;84:172-9. 26 Nathan E, Pedersen S. Dialysis encephalopathy in a non-dialysed uraemic boy treated with aluminium hydroxide orally. Acta Paediatr Scand 1980;69:

Groswold WR, Reznik V, Mendoza A, et al. Accumulation of aluminium in a non-dialysed uremic child receiving aluminium hydroxide. Pediatrics 1983;

edman AB, Miller NL, Warady BA, Lunn GM, Alfrey AC. Aluminium loading in children with chronic renal failure. Kidney Int 1984;26:201-4.

royer $M$, Kleinknecht $C$, Loriat $C$, et al. Growth in children treated with long term hemodialysis. $\mathcal{F}$ Pediatr 1974;84:642-9.

30 Hodson EM, Shan PF, Evans RA, et al. Growth retardation and renal osteodystrophy in children with chronic renal failure. $\mathcal{F}$ Pediatr 1983;103:735-40.

31 Norman ME, Mazur AT, Borden IVS, et al. Early diagnosis of juvenile renal osteodystrophy. $\mathcal{F}$ Pediatr 1980;97:226-31.

Accepted 11 fune 1985)

\title{
Simple mechanical methods for cardioversion: defence of the precordial thump and cough version
}

\author{
G CALDWELL， G MILLAR， ELIZABETH QUINN， R VINCENT， D A CHAMBERLAIN
}

\begin{abstract}
A prospective study was made of the value of the precordial thump and of cough version in life threatening ventricular arrhythmias. Of about 5000 medical and surgical patients, 68 were treated for persistent ventricular tachycardia and 248 for ventricular fibrillation, 86 of whom had presented outside hospital. Mechanical intervention was successful in 26 incidents occurring in 23 patients. Electrocardiographic records were obtained in 14 instances. Ventricular fibrillation was terminated by a thump in five patients and ventricular tachycardia by either a thump or a cough in a total of 17 patients. Four additional instances were recorded of successful recovery from asystolic or unspecified circulatory arrest after a precordial thump. Fifteen patients survived to be dis-
\end{abstract} charged from hospital.

The potential benefit of the precordial thump and cough versions greatly outweighs their risks; hence these manoeuvres should probably be reintroduced into schedules for first aid resuscitation.

\section{Introduction}

Mechanical methods for treating cardiac arrest first attracted attention in 1920, when Schott reported that a blow to the chest restored the heart beat in a patient with an Adams-Stokes attack. ${ }^{1}$

Royal Sussex County Hospital, Brighton, East Sussex BN2 5BE G CALDWELL, BA, MRCP, registrar in medicine

G MILLAR, resuscitation technician

ELIZABETH QUINN, research assistant

$R$ VINCENT, MD, FRCP, consultant cardiologist

D A CHAMBERLAIN, MD, FRCP, consultant cardiologist

Correspondence to: Dr Chamberlain.
More recent reports have described both precordial thumps ${ }^{2}$ and coughing $^{3}$ for the reversion of ventricular tachycardia; precordial thumps may also be effective in ventricular fibrillation. ${ }^{4}{ }^{5}$

Precordial thumps were once recommended widely, but then awareness grew of the possible risk of converting ventricular tachycardia to ventricular fibrillation by such manoeuvres. ${ }^{5}$ The American Heart Association now recommends a precordial thump only at the onset of ventricular tachycardia or fibrillation for patients who are being monitored. ${ }^{6}$ This manoeuvre has been deleted entirely from British first aid manuals. ${ }^{7}$

Evidence for the effectiveness of these physical manoeuvres is often anecdotal. Moreover, the lack of electrocardiographic proof of their success has generated further scepticism. We therefore report our experience of cough and thump version documented as fully as possible in a prospective study carried out over one year from May 1983.

\section{Patients and methods}

The population studied comprised all patients-about 5000admitted to the cardiac care unit, the intensive care unit, or the general medical and surgical wards of this hospital together with any victim of sudden death occurring outside hospital in whom an attempt at resuscitation was made. Of this group, a little over 1000 patients were judged to be at risk of circulatory arrest.

From 1 May 1983 we recorded relevant information from all attempted resuscitations associated with ventricular tachycardia or fibrillation. Whenever possible electrocardiograms were obtained during resuscitation, but in many cases recordings could not be continued during therapeutic interventions.

Patients who were unconscious with cardiac arrest were given a precordial thump over the lower sternum. The initial treatment for ventricular tachycardia, or for ventricular fibrillation of recent onset in patients who were still conscious, was an instruction to cough. If this was unsuccessful a precordial thump was used after explanation to the patient. Subsequent treatment was continued on conventional lines with electrical cardioversion and drugs as appropriate.

We did not measure the force required for the precordial thump, but our practice was to give as firm a blow as possible from a height of $15 \mathrm{t}: 20 \mathrm{~cm}$ above the chest, directed at a point two thirds of the way down the sternum. 
All cases reported here were witnessed by doctors, nurses, or ambulancemen trained and experienced in advanced life support.

\section{Results}

During the study 68 patients were treated for persistent ventricular tachycardia and 162 for ventricular fibrillation. In addition, 86 victims of cardiac arrest outside hospital were seen with ventricular fibrillation, though none had persistent ventricular tachycardia judged to require urgent treatment.

Twenty three patients (mean age 71 years, range 61-85) were successfully treated on 26 occasions by mechanical manoeuvres. In five patients a precordial thump terminated ventricular fibrillation, and in 11 precordial thumps converted ventricular tachycardia to a more normal rhythm. Precordial thumps terminated asystole in two patients, and in a further two thumps corrected circulatory arrest whose cause was unknown. A cough was effective in terminating ventricular tachycardia in six patients. Three patients received interventions which placed them in two categories.

One patient in whom a thump and a cough had been effective for ventricular tachycardia sustained a further episode of this arrhythmia in another hospital. A further precordial thump was given, but on this occasion it resulted in ventricular fibrillation. This was treated successfully by DC shock.

Of the 23 patients who were treated successfully by mechanical manoeuvres, 15 survived to be discharged from hospital.

Electrocardiographic records of rhythms before and after physical manoeuvres had been carried out were obtained in 14 patients; in 12 these recordings were achieved at the moment of successful intervention (figure). Tables I and II give the clinical details of the patients, including those with successful outcome but in whom full records were not obtained (table II).

\section{Discussion}

We believe that this prospective study is the first to record a series of patients with life threatening rhythm disorders who were successfully resuscitated by a precordial thump or a cough, or both. To collect 23 patients having physical interventions with short term success, leading to 15 hospital discharges, depended on close cooperation from doctors, nurses, and ambulancemen experienced in resuscitation. Electrocardiographic records were obtained in 14 cases. In all but two instances, however, the arrhythmia responsible for circulatory collapse was observed on the oscilloscope and no systematic difference was noted between the patients in whom full records were obtained and those in whom they were not.

The underlying rhythm was ventricular tachycardia in 11 of the 14 fully documented cases and in at least half of those where the arrhythmia was observed but not recorded. Most would accept that this is the rhythm most likely to respond to physical manoeuvres. ${ }^{25}$ Ventricular tachycardia may evolve into fibrillation, ${ }^{8}$ although this seems to be rare in the first few hours after myocardial infarction. ${ }^{9}$ Nevertheless, in all of our patients ventricular tachycardia was considered to require treatment because it was persistent or had caused important haemodynamic effects. Physical manoeuvres for ventricular tachycardia have advantages in speed and simplicity of execution. By contrast, electrical cardioversion is rapid but requires anaesthesia, while intravenous antiarrhythmic drugs may be slow to take effect.

In five patients (three of whom had electrocardiograms) a precordial thump converted ventricular fibrillation to sinus rhythm. One case may have been torsade de pointes, which is usually self limiting, but the patient had required electrical defibrillation for similar arrhythmias on several other occasions. Spontaneous reversion of ventricular fibrillation may occur ${ }^{10}$ but is probably rare, certainly in patients with acute coronary disease. Moreover, in several records cough or thump artefact coincided with the moment of conversion, strengthening the belief that these manoeuvres were causal.

The mechanism by which physical manoeuvres terminate ventricular tachycardia or fibrillation is unknown. Usually the arrhythmia stops abruptly, as with electrical conversion, without

TABLE I-Patients with electrocardiographic registration

\begin{tabular}{|c|c|c|c|c|c|c|}
\hline $\begin{array}{l}\text { Case } \\
\text { No }\end{array}$ & Clinical diagnosis & Initial rhythm & Intervention & Subsequent rhythm & $\begin{array}{l}\text { Discharged } \\
\text { alive }\end{array}$ & Comments \\
\hline 1 & Acute myocardial infarction & Ventricular fibrillation & Thump & Sinus & Yes & $\begin{array}{l}\text { Had several episodes of ventricular } \\
\text { fibrillation. One other episode } \\
\text { terminated by thump; unregistered } \\
\text { (not listed separately) }\end{array}$ \\
\hline 2 & Acute myocardial infarction & Ventricular tachycardia & Cough & Sinus & Yes & $\begin{array}{l}\text { Cardiogenic shock due to ruptured } \\
\text { intraventricular septum, repaired } \\
\text { successfully }\end{array}$ \\
\hline 3 & Out of hospital cardiac arrest & $\left\{\begin{array}{l}\text { Ventricular tachycardia } \\
\text { Idioventricular rhythm }\end{array}\right.$ & $\begin{array}{l}\text { Thump } \\
\text { Thump* }\end{array}$ & $\left.\begin{array}{l}\text { Sinus } \\
\text { Sinus }\end{array}\right\}$ & No & $\begin{array}{l}\text { Cause of cardiac arrest unknown. } \\
\text { Found in asystole but after chest } \\
\text { compression had recurrent } \\
\text { ventricular tachycardia and } \\
\text { fibrillation }\end{array}$ \\
\hline 4 & Acute myocardial infarction & Ventricular tachycardia & Thump & Sinus & No & $\begin{array}{l}\text { Cardiogenic shock. Previous mitral } \\
\text { valve replacement }\end{array}$ \\
\hline 5 & Acute myocardial infarction & Ventricular tachycardia & Cough & Rapid atrial fibrillation & Yes & \\
\hline 6 & $\begin{array}{l}\text { Myocardial infarction ( } 6 \text { weeks } \\
\text { earlier) }\end{array}$ & Ventricular tachycardia & Thump & Sinus & Yes & $\begin{array}{l}\text { Second thump for recurrence of } \\
\text { ventricular tachycardia failed to } \\
\text { restore sinus rhythm }\end{array}$ \\
\hline 7 & $\begin{array}{l}\text { Idiopathic conducting system } \\
\text { disease }\end{array}$ & Ventricular fibrillation & Thump & Complete heart block & Yes & Permanent pacemaker implanted \\
\hline 8 & Out of hospital cardiac arrest & Ventricular fibrillation & Thump & Sinus & Yes & $\begin{array}{l}\text { Cause of ventricular fibrillation } \\
\text { unknown }\end{array}$ \\
\hline 9 & $\begin{array}{l}\text { Myocardial infarction ( } 6 \text { weeks } \\
\text { earlier) }\end{array}$ & $\left\{\begin{array}{l}\text { Ventricular tachycardia } \\
\text { Ventricular tachycardia }\end{array}\right.$ & $\begin{array}{l}\text { Thump } \\
\text { Cough }\end{array}$ & $\left.\begin{array}{l}\text { Sinus } \\
\text { Sinus }\end{array}\right\}$ & Yes & $\begin{array}{l}\text { Thump version for ventricular } \\
\text { tachycardia caused ventricular } \\
\text { fibrillation on one occasion. } \\
\text { Recurrent refractory arrhythmias } \\
\text { eventually required ventricular } \\
\text { endocardial resection }\end{array}$ \\
\hline 10 & $\begin{array}{l}\text { Tachycardia-bradycardia } \\
\text { syndrome }\end{array}$ & $\left\{\begin{array}{l}\text { Ventricular tachycardia } \\
\text { Ventricular tachycardia }\end{array}\right.$ & $\begin{array}{l}\text { Cough } \\
\text { Thump }\end{array}$ & $\left.\begin{array}{l}\text { Sinus } \\
\text { Sinus }\end{array}\right\}$ & Yes & $\begin{array}{l}\text { Cough version successful on two } \\
\text { other occasions; unregistered (not } \\
\text { listed separately) }\end{array}$ \\
\hline 11 & Acute anterior infarction & $\left\{\begin{array}{l}\text { Ventricular tachycardia } \\
\text { Ventricular tachycardia }\end{array}\right.$ & $\begin{array}{l}\text { Cough } \\
\text { Cough* }\end{array}$ & $\left.\begin{array}{l}\text { Idioventricular } \\
\text { Sinus }\end{array}\right\}$ & Yes & \\
\hline 12 & $\begin{array}{l}\text { Chronic ischaemic heart disease } \\
\text { (previous myocardial infarction) }\end{array}$ & Ventricular tachycardia & Thump & Sinus & No & \\
\hline 13 & Acute myocardial infarction & Ventricular tachycardia & Cough & Sinus & Yes & \\
\hline 14 & Acute myocardial infarction & Ventricular tachycardia & Thump & Supraventricular tachycardia & No & $\begin{array}{l}\text { Severe left ventricular failure and } \\
\text { cardiogenic shock. One other } \\
\text { episode of ventricular tachycardia } \\
\text { converted to sinus rhythm by } \\
\text { thump. Two episodes of } \\
\text { ventricular fibrillation converted to } \\
\text { sinus rhythm by thump; } \\
\text { unregistered (not listed separately) }\end{array}$ \\
\hline
\end{tabular}

- Two patients (cases 3 and 11) both had incidents in which the same intervention terminated similar arrhythmias. These are counted only once in the results section. 
TABLE II-Patients without electrocardiographic registration*

\begin{tabular}{|c|c|c|c|c|c|c|}
\hline $\begin{array}{l}\text { Case } \\
\text { No }\end{array}$ & Clinical diagnosis & Initial rhythm & Intervention & Subsequent rhythm & $\begin{array}{l}\text { Discharged } \\
\text { alive }\end{array}$ & Comments \\
\hline 15 & Acute myocardial infarction & Ventricular tachycardia & Thump & Sinus & No & \\
\hline 16 & $\begin{array}{l}\text { Exacerbation of severe chronic } \\
\text { bronchitis; respiratory failure }\end{array}$ & Ventricular tachycardia & Thump & Sinus & No & $\begin{array}{l}\text { Ventilated for three weeks. } \\
\text { Pneumonia was terminal event }\end{array}$ \\
\hline 17 & Acute myocardial infarction & Ventricular tachycardia & Thump & Sinus & No & Severe left ventricular failure \\
\hline 18 & $\begin{array}{l}\text { Chronic ischaemic heart disease } \\
\text { and hypertension; septicaemia }\end{array}$ & Ventricular tachycardia & Thump & Sinus tachycardia & No & $\begin{array}{l}\text { Thump terminated ventricular } \\
\text { tachycardia twice }\end{array}$ \\
\hline 19 & Non-accidental poisoning & Asystole & Thump & Sinus & Yes & \\
\hline 20 & $\begin{array}{l}\text { Out of hospital cardiac arrest; } \\
\text { idiopathic conducting system } \\
\text { disease }\end{array}$ & Ventricular fibrillation & Thump & Sinus & Yes & \\
\hline 21 & $\begin{array}{l}\text { Chronic ischaemic heart disease } \\
\text { (previous myocardial infarction, } \\
\text { diabetes) }\end{array}$ & Unknown & Thump & Sinus & Yes & $\begin{array}{l}\text { Collapsed on ward cyanosed with no } \\
\text { pulse or respiration }\end{array}$ \\
\hline 22 & $\begin{array}{l}\text { Congestive heart failure; intrinsic } \\
\text { asthma; chronic bronchitis }\end{array}$ & Unknown & Thump & Sinus & Yes & \\
\hline 23 & $\begin{array}{l}\text { Conducting system disease; } \\
\text { rheumatic heart disease }\end{array}$ & Asystole & Thump & Not recorded & Yes & $\begin{array}{l}\text { Output restored several times by } \\
\text { precordial thump }\end{array}$ \\
\hline
\end{tabular}

- One patient (case 14) listed in table I with ventricular tachycardia as initial rhythm had thump version from unregistered ventricular fibrillation on two occasions.
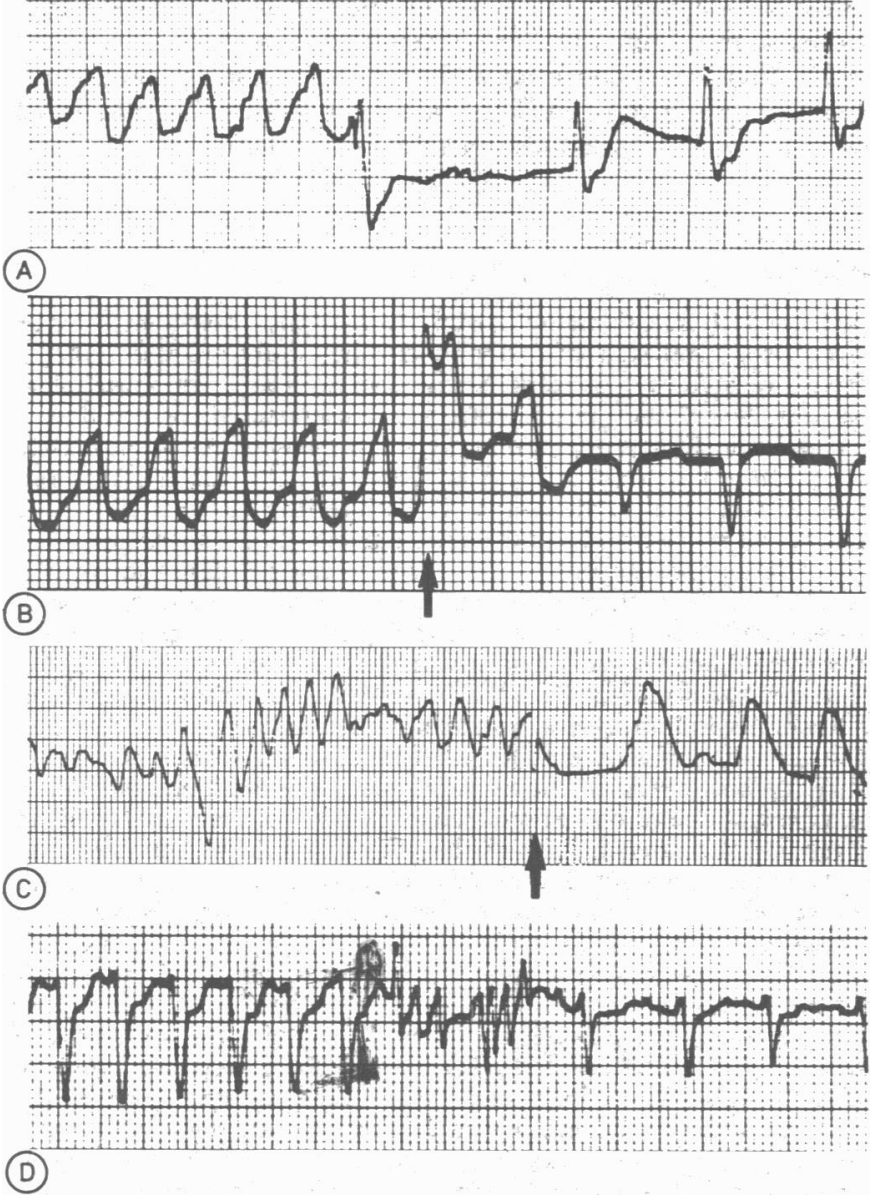

Sections of electrocardiographic tracings before and after therapeutic physical manoeuvres. A (case 4): thump version of ventricular tachycardia to atrial fibrillation. B (case 9): thump version of ventricular tachycardia to sinus rhythm. $C$ (case 1): thump version of ventricular fibrillation to idioventricular rhythm which rapidly reverted to sinus rhythm. Several similar episodes required electrical defibrillation. D (case 10): cough version from ventricular tachycardia to sinus rhythm. In this monitoring lead configuration of original complexes resembled that of supraventricular rhythm, though width was greater. Arrows in B and C indicate point of intervention.

an additional premature extrasystole; a small depolarising current may be induced by electromechanical transduction. It may be relevant that ventricular tachycardia often requires only a low energy discharge for cardioversion and also responds commonly to physical manoeuvres. Arrhythmias requiring higher energies generally do not respond. The episodes of ventricular fibrillation which were terminated with thumps were all of very recent onset: we do not know the usual requirement for defibrillating energy in the first moments of fibrillation, but it may change rapidly with the electrical and metabolic consequences which ensue.

Standard first aid manuals in Britain ${ }^{7}$ and the United States ${ }^{6}$ do not recommend the use of a precordial thump as an initial manoeuvre during cardiac arrest. We believe, however, that the danger of physical manoeuvres should not discourage their use. ${ }^{511}$ If a patient is pulseless as a result of ventricular tachycardia, ventricular fibrillation, or asystole for long enough to justify a resuscitation attempt then spontaneous recovery is unusual. Our experience with at least eight patients who were pulseless makes it clear that intervention is more likely to be beneficial than harmful; and little time is lost if the intervention is without effect. It should be noted that all antiarrhythmic drugs have proarrhythmic effects ${ }^{12}$ and that electrical cardioversion itself may cause deterioration of arrhythmias. ${ }^{1314}$

We recommend that all conscious patients with a ventricular tachycardia warranting treatment should be asked to cough forcibly. Those who do not respond should be given a precordial thump only if the arrhythmia demands urgent action; adequate explanation should be given and back up electrical defibrillation should always be available. The opportunity to invite a cough in the presence of ventricular fibrillation is brief because consciousness is lost quickly. Thump version may occasionally be useful for this arrhythmia, but we suspect that delay before treatment greatly influences the prospects for success. In our view the precordial thump should be used "blindly" in all unmonitored patients who develop circulatory arrest; it may be successful early after the onset of ventricular fibrillation and during a longer period if the rhythm is rapid ventricular tachycardia or asystole. The risks in these settings are outweighed by the potential benefits. We favour the reintroduction of the precordial thump in first aid manuals and believe that the results of our study may justify this recommendation.

Elizabeth Quinn is in receipt of a research grant from the South East Thames Regional Health Authority.

\section{References}

1 Schott E. Uber Ventrikelstillstand (Adams-Stokes'sche Anfalle) nebst Bemerkemgen uber andersartige Arhythmien passagerer. Deutsches Arch Klin Med gen uber anders

2 Pennington JE, Taylor J, Lown B. Chest thump for reverting ventricular tachycardia. N Engl $\mathcal{f}$ Med 1970;283:1192-5.

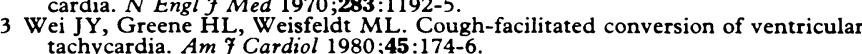

4 Harwood-Nash DCF. Thumping of the precordium in ventricular fibrillation. $S$ Afr Med $\mathcal{F} 1962 ; 36: 280-1$

5 Adgey AAJ, Webb SW. The treatment of ventricular arrhythmias in acute myocardial infarction. Br $\mathcal{F}$ Hosp Med 1979;21:356-79.

6 American Heart Association. Defibrillation and synchronized cardioversion. Text- 
book of advanced cardiac life support. Dallas: American Heart Association,

7 St John Ambulance Association, British Red Cross Society. The first aid manual. London: Dorling Kindersley Ltd, 1982.

8 Kempf FC, Josephson ME. Cardiac arrest recorded on ambulatory electrocardiograms. Am f Cardiol 1984;53:1577-82.

9 Campbell RWF, Murray A, Julian DG. Ventricular arrhythmias in first 12 hour of acute myocardial infarction. Natural history study. Br Heart $\mathcal{f} 1981 ; 46$ :

10 Adgey J. Pre-hospital coronary care with a mobile unit. In: Colling J, ed. Coronary care in the community. London: Croom Helm, 1977:120.
11 Sclarovsky S, Kracoff OH, Agmon J. Acceleration of ventricular tachycardia induced by a chest thump. Chest $1981 ; 80: 596-9$.

12 Chamberlain DA. Management of arrhythmias. In: Maseri A, Goodwin J, eds. Hammersmith cardiology workshop series. Vol 1. New York: Raven Press, 1984. 3 Graf WS, Etkins P. Ventricular tachycardia after synchronized direct-current

14 Desilva RA, Graboys TB, Podrid PJ, Lown B. Cardioversion and defibrillation. Am Heart $\mathcal{F}$ 1980;100:881-95.

(Accepted 2 fuly 1985)

\title{
Snoring as a risk factor for disease: an epidemiological survey
}

\author{
PETER G NORTON， EARL V DUNN
}

\begin{abstract}
In a study conducted in four family practice units in Toronto, Canada, 2001 subjects reported on snoring and medical conditions in members of their households. For spouses the prevalence of snoring increased with age up to the seventh decade, with a higher prevalence of nearly $85 \%$ in husbands. For 11 medical problems an association existed between snoring, its frequency, and the presence of the condition. This association continued when the data were corrected for sex, age, and marital state. For hypertension both men and women who snored between the fifth and 10th decades had a twofold increase over non-snorers. The prevalence of heart disease and other conditions, except for diabetes and asthma, also increased in snorers in this age group. When corrected for smoking and obesity the association between snoring, hypertension, and heart disease persisted.

These findings extend those of Lugaresi et al, and if they could be confirmed snoring as a risk factor for conditions other than sleep apnoea and sleep disorders might be considered. Methods of alleviating the acoustic annoyance of snoring may also provide direct medical benefits.
\end{abstract}

\section{Introduction}

Snoring is a common condition. In a study of nearly 6000 people living in San Marino Lugaresi et al stated that $40 \%$ of men and $28 \%$ of women snored, with increasing prevalence up to the seventh decade, when over $60 \%$ of men and $40 \%$ of women were found to be habitual snorers. ${ }^{12}$ In an earlier study we found that snoring occurred in over half of the adult population, with $86 \%$ of wives reporting their husbands as snorers and $57 \%$ of husbands reporting their wives as snorers. ${ }^{3}$ Associated with sleep apnoea and other sleep disorders snoring has been a topic of medical discussion for several years and has even been considered a risk factor for sudden death in infants. ${ }^{45}$

Reports have recently speculated that snoring may be a risk factor for other diseases, ${ }^{6-9}$ and so its physiology ${ }^{10}$ and possible concurrent conditions are to be considered.112 Lugaresi et al have shown that snoring is associated with hypertension. ${ }^{211}$ In a previous unpublished pilot study we too noted that there

\footnotetext{
Department of Family and Community Medicine, University of Toronto, Ontario

PETER G NORTON, PHD, MD, assistant professor

EARL V DUNN, MD, professor
}

Correspondence and requests for reprints to: Dr Peter Norton, Sunnybrook Medical Centre, 2075 Bayview Avenue, Toronto, Ontario M4N 3M5. seemed to be an association between snoring and several medical problems, most notably hypertension, but we have found no reports that have considered the risk of snoring alone, unassociated with sleep apnoea or other conditions. We made this survey to see if such associations could be elicited.

\section{Methods}

We used a questionnaire tested in the pilot study mentioned above. Over 2000 visitors to four different family practice units in Toronto responded to questions about snoring in their households. The units where the questionnaire was administered serve different populations including upper, middle, and lower socioeconomic classes and several ethnic groups. Thus we hoped to get a broad ethnic and economic range within the sample. In each setting a sequential sample was taken of those who volunteered to answer the questionnaire (over $85^{\circ}$ of those approached), and the most common reason for refusal was that they were too busy to complete the questionnaire. A research assistant was present to make sure the questionnaire was completed correctly and answer any questions the respondents might have.

The reporters recorded basic demographic data about themselves and then listed all members of their households, completing a section for each member that ascertained whether he or she snored, how often, and conditions that made the snoring worse. The definition of snoring was a general one of noise produced while sleeping, but it was left to the reporters to interpret this as they saw fit, thus the definition was based on the respondent. The reporter noted on a provided list whether the reportee suffered from any of 13 general medical problems such as heart disease, chest disease, and allergies. Thus the data were not self reported but observed by members of the household. Medical records were not reviewed.

The responses to the questionnaire were collated and analysed with a computer program developed by ourselves. Each response could be analysed in relation to both the reporter and the reportee. For the total sample the group who were reported to snore every night, those who were reported to snore nearly every night, and the group of occasional snorers and non-snorers were compared using the $\chi^{2}$ test for trend with weights of six, five, three, and one, respectively. ${ }^{13}$ Levels of significance of 0.001 are shown. Other data were analysed with the $\chi^{2}$ statistic comparing snorers with non-snorers. Levels of significance of 0.05 and 0.01 are given.

\section{Results}

Within the four units 2054 questionnaires were completed, with over 500 from each site. After incomplete or unusable questionnaires were eliminated (early in the study some respondents completed data only on snorers even though they were asked to complete the items for all members of the household) 2001 usable questionnaires remained, reporting on 2629 subjects.

The profile of the reporters was similar to the population of Toronto and included persons from all ages, ethnic backgrounds, and economic strata. The reporters included 691 men and 1304 women. In six cases the gender of the reporter was not recorded. Ages varied widely among 